\title{
AN ANALYSIS OF LIBERAL FEMINISM IN THE NOTEBOOK NOVEL (1996) BY NICHOLAS SPARKS
}

\author{
Pande Made Gunawati \\ English Language Education, Universitas Pendidikan Ganesha \\ e-mail: pandemadegunawati@gmail.com \\ Dewa Komang Tantra \\ English Language Education, Universitas Pendidikan Ganesha \\ e-mail: dewatantra@yahoo.com \\ Putu Adi Krisna Juniarta \\ English Language Education, Universitas Pendidikan Ganesha \\ e-mail: adiputu108@gmail.com
}

\begin{abstract}
In The Notebook by Nicholas Sparks, Allison Nelson was characterized as an inspiring woman who fought for her dreams. Meanwhile, Noah Calhoun was described as a loving man that respected Allison as a woman. This novel contained traits of rich liberal feminism. The purpose of the present research was to find out the traits of Noah Calhoun and Allison Nelson as the main characters that represented liberal feminism in the novel. The method of this research was textual analysis to analyze the traits. Data collection was linguistics unit corpora recorded in written forms. The finding of this research can be stated that Noah Calhoun and Allison Nelson were categorized as liberal feminists. Their traits were a combination of positive feminine and masculine traits. The traits of the main characters as liberal feminists were appreciative, forceful, strong, devoted, firm, sensitive, confident, patient, carefree, responsible, and independent.
\end{abstract}

Keywords: liberal feminism, the notebook, appreciation

\section{INTRODUCTION}

Nicholas Sparks is one of the best seller authors in New York City. Nicholas Sparks' novel succeeds to attracts readers' attention. He writes his novels with great details that made readers can imagine every event in the novel as if the readers were in the novel (Roifah, 2014). Not only readers' attention but Spark's works also attracted by movie producers. It makes many of his novels turned into films adaptation. One of Nicholas Sparks' novel that popular in book and film version is The Notebook. Nicholas Sparks' famous novel The Notebook told an eternal affection between a romantic couple that touched the readers' hearts (Joy, 2019).

The notebook novel by a famous author Nicholas Sparks was about a romantic couple who struggle to be together, although many problems came to their life. The affection shared by a young inseparable couple named Noah and Allison. Noah Calhoun was a countryman, and Allison Nelson was a middle-class woman. They came from a different family status. Noah's father worked in a lumberyard. In contrast, Allison and her parents were considered wealthy families. Their romantic story began when Allison 
went to New Bern to enjoy her summer holidays. Finn and Sarah introduced Allison to a county boy named Noah. Allison and Noah started to spend days together visiting certain places in New Bern. Then, they were falling in love with each other. They fight for their love even though Allison's parents disapprove of them being together. Allison was forced to leave Noah. Since then, they lost contact. After separated for 14 years, Allison went back to New Ben for telling Noah that she was getting married to Lon. However, after they reunited again, they feel the love that had never been forgotten toward each other. Their love became stronger. There are many obstacles to Noah and Allison's relationships, but their love last forever. Eventually, the Doctor diagnosed Allison with Alzheimer's. She forgot about everything. Noah never gave up on her. He read Allison The Notebook, and it brought a miracle to Allie, where she could remember Noah again. The story between Allison and Noah succeeds in making readers cried. It means that the author of the novel manages to influence readers' feelings.

Authors have aims in writing their novels. Those are to amuse, persuade, and to give information to readers. Authors send their message to readers through their works. The massages can be motivated, inspiring that will influence readers' life. The authors write a novel in a particular theme that aims to show their idea about something (Jayanti, 2013). An example of the ideology that the writers reveal in their novels is an ideology of feminism. The Notebook novel contained traits of rich liberal feminism. This novel tells about an older man who respects her wife suffering from Alzheimer's disease. The novel published in October 1996. The Novel was released when the feminism movement is rife in society.

Women's actions, such as feminism, occurred in many places, including Indonesia. It happened in the history between the nineteenth and twentieth century, such as spearheaded by Raden Ajeng Kartini (Lubis, 2006). She was considered as feminist. Because she fought for opportunities to be given to women, such as their rights in education, she was inspired by society because of her forward movement. However, gender equality issues still exist in society, no matter how the government makes programs to eliminate it. The report of Global Gender Gap 2015 that was released by the World Economic Forum (WEF) displayed of Indonesian position for the survey of 145 countries, Indonesian rank was 92, far behind Philippian, which located in 9 places. Gender equality in Indonesian is large enough, and the score was 0,6813 (Murthi et al., 2017).

In the feminist perspective, the position of men and woman are equal. Therefore, they could do things as men do in public. As stated by (Tong, 2009), As seen by liberal feminists, it is not a proper way to discriminate against women. Many opportunities should be given to women. Bett Friedan stated that feminists should stop trying to become and do everything because a woman can be housewife and workers as well. A woman can be a wife and mother. If the woman did not have a career, it would limit their growth (Tong, 2009). If feminism wants to be something alive and developing, it must be started by recreating a wheel that means to find not only new issues but a new language (Walters, 2005). Therefore, many novels about feminism are written to educate readers about the importance of gender equality. In the bestseller novel The Notebook, Noah Calhoun and Allison Nelson are considered as feminists.

Feminism does not necessarily aspire by women but men as well. It has a relation to the theory of gender. It concerned with the development of self that implied the theory when someone thinks, perceives, acts, and speaks which not culturally specific of women but men as well (Disch, 2018). In this research, the main characters, namely, Allison 
Nelson and Noah Calhoun, have been chosen to be analyzed using feminist theory by (Tong, 2009) because they are the main characters that dominate the story and always appear in every chapter of the novel. The main character frequently influenced the flow of the story in the novel. Therefore, based on the background above, the researcher will analyze the main characters' traits that represent liberal feminism in the bestseller novel The Notebook by a success author Nicholas Sparks.

\section{METHOD}

Qualitative research was done with intense contact with the field in life. The situation is expected to be normal, which reflected the daily life of a person, group, community, and society (Miles \& A. Huberman, 1994). The data collection of the research is obtained from the famous novel The Notebook by a successful author Nicholas Sparks. The data were taken from all sentences as the content of The Notebook. The data were taken from all sentences as the content of The Notebook. There are two steps in collecting the data, namely reading and identifying. The research data analysis method is textual analysis. By using textual analysis, the researchers will make possible interpretations from the text (McKee, 2003). The research method of textual analysis applied for analysis to help the researcher to describe and interpret the characteristics (Frey, Bontan, \& Kreps, 1999). There are twelve chapters in the famous novel The Notebook by a successful author Nicholas Sparks. Every Chapter from the novel is considered as the integral linguistics corpus. The liberal feminist's traits will be extracted from the integral linguistics corpus.

\section{FINDING AND DISCUSSION}

The present research focuses on the liberal feminism traits extracted from the bestseller novel The Notebook by famous author Nicholas Sparks. In general, the story told the eternal love between an inseparable couple named Noah Calhoun and Allison Nelson that spanned for over fifty years. Their love was complicated. They faced many difficulties, such as being separated for 14 years, the sadness and happiness of World War II, the loss of one of their favorite children, and the diagnosis of Allison of Alzheimer's disease. There are twelve chapters in the novel. Every Chapter from the novel is considered as the integral linguistics corpus. The liberal feminist's traits will be extracted from the integral linguistics corpus.

Liberal feminism is kind of feminism which focused on the liberal feminism traits to get the gender equality between man and woman. Liberal feminists believe that if everyone in the society supports the combination between positive masculine and feminine traits, then everyone will get equality, and there is no one thinks that women are subordinate to men (Tong, 2009). The combination of feminine and masculine is the idea of androgyny (Brannon, 2015). There were eleven traits of the combination between positive masculine and feminine. Those are patience, sensitivity, devotion, responsibility, appreciation, strength, confidence, firmness, force, carefreeness, and independence (Brannon, 2015). Eleven liberal feminist traits occur in the popular novel The Notebook.

The first trait of liberal feminist that stand out, among other traits is appreciation. The trait of appreciation frequently occurred in the novel. In The Notebook by Nicholas Sparks, Allison Nelson, and Noah Calhoun is described as appreciative characters. They tend to appreciate each other. The explanation above was related to the quotation below. "She paused, then looked past him toward the house. "You did a wonderful job restoring it. It looks perfect, just like I knew it would someday" (Sparks, 1996). The quotation 
showed Allison's appreciation of Noah's success in restoring his house. After Allison arrived at Noah's house, she was amazed by the look of the house. His house was described as the oldest and biggest house in New Bern. His house also had electricity. In fact, a reporter had made an article about Noah's house. Allison compliments Noah's beautiful restoration house. From her statements, it can be seen that Allison praised Noah for his excellent job in making a wonderful house. Allison's compliments to Noah's house is considered as the trait of appreciative. In line with (Payani, Suwastini, \& Swandana, 2018), who found that giving respect and appreciation to others is an example of the act of appreciative.

Moreover, Noah showed the trait of appreciation when he complimented Allison's beautiful appearance. Allison was an attractive woman with a pair of ocean eyes. The explanation above related to the quotation below. "I'm glad you did." He stepped back just a bit. "God, you look fantastic. You're even prettier now than you were then" (Sparks, 1996). The quotation showed Noah's appreciation of Allison's beautiful' appearance. He smiled broadly toward Allison's visitation to his house. He was grateful to see her again after separated for 14 years. He believed that Allison looked more beautiful since the last time he saw her. Noah gave Allison a sincere compliment to her beauty. Noah Calhoun has the trait of appreciation because he supports Allison by giving her encouragement through compliments. Accordance with (Hendriana \& Jacobus, 2016), who found in their research that rewarding to someone for their works, showing signs of achievement awards, creating a motivating atmosphere is the act of promoting appreciative character. The trait of appreciation commonly appears in the novel because of Noah and Allison's love and respect towards each other. They gave support by praising each other.

The second trait of liberal feminist that stand out, among other traits is force. The trait of force frequently occurred in the novel. Allison and Noah are described as forceful characters. Allison also showed the trait of force when she forced her will to Noah on going to canoeing to the lake. It was expressed in the quotation, "She thought for a second while she looked around. When she spoke, her voice was determined. "Then we'll go. I don't care if it rains" (Sparks, 1996). The quotation showed Allison's trait of force when she insisted Noah to go with her. Although Noah already warned her that it was going to be rain, she did not care about it. Allison was forceful. She insisted Noah to go with her, although the weather was bad. Allison also insisted Noah to give her a clue about the place that they were going to visit. Her statement was shown that she was strongly forceful because her argument could influence others. Friedan insisted that men should develop their passive feminine qualities such as nurturing, and women should develop their masculine qualities, such as brave, forceful, adventurous, and dominant (Tong, 2009).

Furthermore, Noah also showed the trait of force when he broke the hospital rule just to see Allison. It was seen from Noah's conversation with the nurse named Janice.

"Then, you know you shouldn't be doing this."

I don't answer directly. Instead, I say, "I miss her."

"I know you do, but I can't let you see her."

"It's our anniversary," I say" (Sparks, 1996).

The quotation above showed that Noah insisted on seeing Allison at night in her room. The nurse already prohibited him, but he insisted on going to visit Allison without the nurse's permission. Janice did not let him ago, but he forcefully must go because it was his forty-nine Anniversary with Allison. Although Noah could not walk normally like other people, he tried so hard to walk in the hope of seeing Allison. His body was painful 
when he moved. However, the thought of seeing Allison made him felt stronger. The trait of forceful was shown by Noah because he has a strong argument to defend his intension. Forceful also defined as the expression of showing an argument with force and demand for attention or action (Cambridge Dictionary, 2020).

The third trait of liberal feminist that stand out, among other traits is strength. The trait of strength frequently occurred in the novel. The trait of strength was represented by Allison through Noah's perception of Allison and her mother's behavior. It was expressed in the following quotation, "She was a strong woman, he thought to himself, and he knew where Allie got it from" (Sparks, 1996). The quotation showed that Allison was a strong woman. Allison had been through many obstacles. Allison was insecure in facing her problems, but she was, though. She faced her problems bravely. Allison became stronger as she passed many difficulties in her life. She could stand tall and become stronger, although she faced her problems. Noah believed that Allison got her strength trait from her mother. Noah could tell it by looking at the behavior of Allison's mother. Allison's mother left Noah's house without regret. She never looked back. Allison's strength had been proven in dealing with difficulties. She could face it bravely as her mother did. A mother has a significant influence on her daughter, as stated by Boyd in (Swirsky \& Angelone, 2014), especially for a woman who lived around feminists. It will perhaps influence their way of thinking. For example, a mother has a big influence on her daughter as someone that very close to her life.

Noah, as a male character in the novel, also had a strong trait. Noah's strength was shown in Allison's perception of him. Noah could survive from a difficult world, as expressed in the quotation below. "She had seen too many men in the past few years destroyed by war, or time, or even money. It took strength to hold on to inner passion, and Noah had done that" (Sparks, 1996). The quotation showed that Noah was strong. He could survive from war, hard times, and the difficult moment in finding money. He could live in a worker's world as a poet. Allison had known many men that had faced difficulties in their life, but none of them resembled Noah. Noah was different from other men. He had the strength to face the challenging world. It is in line with (Fakhrian \& Islamiyati, 2017) who found that a strong woman had been through challenges in her past life.

The fourth trait of liberal feminist that stand out, among other traits is devotion. The trait of devotion frequently occurred in the novel. Allison showed her devotion when she knew that she was suffering from Alzheimer's disease. It was expressed in Allison's words in the letter that she gave to Noah, "And I am so sorry if I am not able to tell you. I love you deeply, my husband. You are, and always have been, my dream” (Sparks, 1996). The quotation showed that Allison's devotion toward Noah. She was more worried about Noah's feelings than her disease. She still loved Noah, although she does not remember him. Allison wrote a final letter to Noah and asked to read it often because the love letters told Allison honest feelings to Noah, and the love story that was written in the notebook was a reminder of their happy moment that they shared together. Allison loved Noah so deeply. She would always love him in every condition. Different from man, women have main instincts that higher and holier than self-defense: instincts of a loving mother, the devotion of wife, the loyalty of sisters, the loyalty of daughter (Marilley, 1996). 
The liberal feminist of devotion was also shown by Noah. Noah, as the male main character in the novel, has the trait of devotion. He always read the notebook to Allison. In the notebook, their love story was written. Noah had a reason for reading the book. It was expressed in the quotation,

"I have read to her this morning, as I do every morning, because it is something I must do. Not for duty although I suppose a case could be made for this but for another, more romantic, reason" (Sparks, 1996).

The quotation above showed that Noah was devoted to Allison. He showed his devotion through his action in expressing his love for Allison by his action. He read to Allison every morning despite his illness. He did that for romantic reasons. Noah believed that by reading Allison the notebook, the miracles would come to his life through Allison's condition. Noah loved Allison since the first day he met her at the River festival. Noah loved her until they are old. He still loved Allison, although she did not remember him because of Allison's Alzheimer's disease. Noah showed the liberal feminist trait of devotion. He could not live without Allison. Although Noah has low self-esteem, he never gives up to fight for his love. Noah has a great devotion to Allison. His devotion involves dedication, passion, and intimacy (Fajarini, 2015). Noah, as the main character of the novel, appeared to be devoted and willing to use all his effort to get his love (Fajarini, 2015).

The fifth trait of liberal feminist that stand out, among other traits is firmness. The trait of firmness frequently occurred in the novel. Allison and Noah were described as firm characters. Allison's firmness was shown when she explained to Lon that she would stay with Noah. It can be seen from Noah's letter that he gave to Allison.

"Even as you explained that you had always loved me and that it wouldn't be fair to him, he did not release your hand. I know he was hurt and angry and tried for almost an hour to change your mind, but when you stood firm and *sack, "I can't go back with you, I'm so sorry," he knew that your decision had been made. You said he simply nodded, and the two of you sat together for a long time without speaking" (Sparks, 1996).

The quotation above proved that Allison was firm. Noah's letter discussed the things that happened when Allison met Lon in the lobby. She has made her decision. It was hard for her to leave Lon. She cared for him, and he cared for her too. It was the hardest decision that Allison had made. Lon tried his best to change Allison's decision, but he could not do that because Allison had already chosen what best for her life. Allison chose Noah. It showed Allison's firmness that she never doubts Noah's feelings for her. Therefore, she did not change her decision even though Lon tried many times to win her heart. The firmness also defined as cannot be disturbed or change, for instance, a firm believer in God (Merriam-webster, 2020).

Similar to Allison, Noah also showed firmness in the novel. Noah was a hardworking person. Nothing could stop him from working hard every day. Noah's firmness in working hard expressed by his friends Gus, in the quotation, "I been watchin' you, workin' day and night, slavin' so hard you barely have time to catch your breath" (Sparks, 1996). The quotation showed that Noah's firmness. Noah worked hard to fix his house. He had reasons for it. Noah worked hard to finish his house. Besides, Working hard made him forget about his problems. After Allison left him, He had a difficult time to forget her. She always popped up in his mind. Noah learned that by being busy, it could make him forget about Allison. Firmness is a term that is used to someone who is not weak towards the things that happened to him or her (Dinata, 2011). 
The sixth trait of liberal feminist that stand out, among other traits is sensitivity. Allison's showed her sensitivity mostly through her emotion toward the thing that happened to her. The trait of sensitivity that shown by Allison was when she could feel something that others did not notice, as expressed in the following quotation,

"Her eyes brimmed with tears as they finally released each other. She laughed nervously under her breath while wiping the tears from the corners of her eyes" (Sparks, 1996).

The quotation above proved that Allison was sensitive in dealing with her feelings. Allison was easy to be emotional when it was related to her feelings. She was crying when she saw Noah again. She regretted her decision to visit Noah without telling him first. She taught that Noah did not recognize her. Allison was emotional when meeting Noah again. Sensitive is carefully realizing other's behavior or feeling (Merriam-webster, 2020).

Allison also never stops crying when she must leave Noah again and when to the hotel to meet Lon. It was expressed in the quotation below.

"Stay with me," Noah mouthed without sound, and this, for some reason, hurt more than Allie would have expected. The tears began to fall hard now, but she couldn't speak. Finally, reluctantly, she looked away and pulled her hand from his." (Sparks, 1996).

The quotation above showed that Allison was fragile when she has many problems to handle. Allison was sensitive. Noah's words made her feet hurt when he asked her to stay with him. The tears are streaming down her face. The other definition of sensitive people is they are conscious of the somatic symptoms, that did not recognize by other (Grimen \& Diseth, 2016).

The seventh trait of liberal feminist that stand out, among other traits is confidence. Allison showed confidence in most of the chapters in the novel. It was expressed in the quotation,

"Traits like intelligence, confidence, strength of spirit, passion, traits that inspired others to greatness, traits he aspired to himself. Allie had those traits, he knew, and as they walked now, he sensed them once again lingering beneath the surface" (Sparks, 1996).

The quotation above showed that Allison was confident, based on Noah's perception. She was confident since she was a young girl. Noah noticed that confidence was one of her best traits. Allison was not only beautiful, but she had the traits that others did not have. The traits are confidence and intelligence. Many women earned experience and confidence by taking a more active role in government and another public part (Walters, 2005).

The trait of confidence is shown by Noah. He was confident in predicting the weather. It was expressed in the following quotation,

"The morning haze he knew the stiffness noted that his legs were still hadn't burned off yet, and in his legs usually predicted rain. He looked to the western sky and saw storm clouds, thick and heavy, far off but definitely present" (Sparks, 1996).

The quotation above showed that Noah was confident in his instincts. He knew when it was going to be rain. He used his instinct to predict it. He believed that his instincts were always right. Confidence is described as showing or having a confident ability (Crowther, 1995).

The eighth trait of liberal feminist that stand out, among other traits is patience. The trait of patience frequently occurred in the novel. The trait of patience was also shown by Allison when she dealt with Lon's business. It was expressed in the quotation, "She didn't like to argue with him about it, mostly because she knew he was telling the truth. Trial work was demanding, both beforehand and during, yet she couldn't help 
wondering sometimes why he had spent so much time courting her if he didn't want to spend the time with her now" (Sparks, 1996).

The quotation above showed that Allison understood Lon's condition. She never complains to Lon whenever he did not have time to see her. She understood that he was busy. Allison's patience trait was shown when she did not get angry with Lon. Patience is the ability to keep doing something in difficult times, or suffering, or waiting without being angry or complaining (Cambridge Dictionary, 2020).

Noah also showed patience in dealing with Allison's illness, as expressed in the following quotation, "Yes," I say again, just as I do every time on days like these. I have learned to be patient" (Sparks, 1996). The quotation showed that Noah patiently took care of Allison when she was ill. He tried to control himself by not giving to much information to her because he learned that it would make her afraid to him. Allison's reaction will hurt Noah's feelings. Noah was patient in dealing with Allison's Alzheimer's disease. Allison did not remember him. The example of patience is shown in dealing with uncomfortable situations or temporary postponement, such as traffic jams Schnitker in (Bülbül \& Arslan, 2017).

The ninth trait of liberal feminists that stand out, among other traits, is carefree. The trait of carefree frequently occurred in the novel. Allison was carefree and happy about Noah's surprise. It was expressed in the quotation,

"Noah brought out the bag of bread he'd brought earlier and handed it to Allie. She scattered the bread, favoring the little ones, laughing and smiling as they swam in circles, looking for food" (Sparks, 1996). The quotation above showed that She was excited to feed the geese with bread. Being carefree means having a mental life where somebody is going through their world without responsibility and worry for a significant level although there are times when they are going through several negative emotions related to anxiety and stress (Ferracioli, 2020).

Noah was similar to Allison. He showed his carefreeness by being close to Allison. It can be seen in the quotation, "It's been quite a night," he said, his voice softer now. "Yes, it has," she said, "a wonderful night" (Sparks, 1996). The quotation showed that He was glad that he could see her again after the long separation. Allison showed the trait of carefree through her happiness toward the reunion. She could talk again and having a conversation with Noah. Allison shared her life story with Noah without worries. She talked to Noah until dark. A carefree person is enough without the feeling of worries and responsibility because of the psychological improvement or personal condition and their social politics (Ferracioli, 2020).

The tenth trait of liberal feminist that stand out, among other traits is responsibility. The trait of responsibility frequently occurred in the novel. Allison and Noah showed their responsibility for the decision that they made. Allison was responsible for her problem. It was expressed in the following quotation, "I'm sorry," Allie said. I had no idea this would happen." (Sparks, 1996). The quotation showed that Allison has the trait of responsibility. Therefore, she faced it bravely. Allison was responsible. Allison felt bad for the conflict that happened when her mother visited Noah's house. She said sorry to Noah. Allison shows the trait of responsible in apologizing to Noah for the uncomfortable situation. Some actions of responsibility are doing tasks based on their own initiatives, doing work regularly, participated in many activities, and offered solutions to a problem (Hendriana \& Jacobus, 2016:29). 
Noah was responsible for his guest. He lent Allison to change clothes because her clothes are wet. It was expressed in the quotation, "I think I can find something here for you so you can get out of those clothes. It might be a little big, but it's warm." (Sparks, 1996). The quotation above showed that Noah shows the liberal feminist trait of responsible. He was the one who invited Allison to spend the day on the water. Therefore, he lent her his clothes for a change. Responsible means having control or power for someone or something, and the job is to take care of them (Cambridge Dictionary, 2020).

The eleventh trait of liberal feminist that stand out, among other traits is independence. The trait of independence frequently occurred in the novel. Independence assumed as someone who depends only on themselves, not other people (Eidelweis, 2018). Allison and Noah showed their independence similarly. Allison showed her independence by refusing other's help to solve her problem. It was expressed in the quotation, "She shook her head. "No. Not really. I have to do this alone" (Sparks, 1996). The quotation above showed that Allison showed her independence. She did not depend on others in solving her problems. She believed that she could face her problem alone. Allison said that she must face Lon alone. Liberal feminism emphasizes the value of individualism and independence as the opposite of the essentials of weblike relationships and relation to all life and natural sources Ibid in (Tong, 2009). Independent women did not depend on other's opinions.

Similar to Allison, Noah also had a trait of independence. The man showed his independence as expressed in the quotation below, "The path is straight as ever, but it is strewn with the rocks and gravel that accumulate over a lifetime" (Sparks, 1996). The quotation above showed that The life path that the narrator has chosen to follow was indeed a choice. Allison's refusal for Noah's help showed her independence, which was in line with (Rastina, Sili, \& Nasrullah, 2019), who found that independence can be shown from the refusal of other's help. Feminists believed that someone can live independently and can be successful without other's assistance (Eidelweis, 2018).

\section{CONCLUSION AND SUGGESTION}

This research identified the traits of the main characters as a liberal feminist in The Notebook by Nicholas Sparks. From the research result in the previous discussion, the conclusion is drawn related research problem and objective. There are eleven traits of Allison Nelson and Noah Calhoun as a liberal feminist, namely appreciation, force, strength, devotion, firmness, sensitivity, confidence, patience, carefree, responsibility, and independence

First, a trait of appreciation, Allison and Noah, appreciated other works by giving the compliment to them. They also treated others with respect and gratitude. Second, a trait of forceful, once they made a decision, they would stick with it forever. They stated what they wanted directly. Third, a trait of strength, Allison, and Noah learned that nothing could break them from all the difficulties that they had experienced in their life. Fourth, a trait of devotion, Allison and Noah loved each other, and no one can separate them. Fifth, a trait of a firm, They took a decision seriously. They decided what good to them, even it took a lot of time to make it. They did not change their opinions. Sixth, a trait of sensitivity, Allison, and Noah are fragile in dealing with their feelings. They are easily triggered by the situation that makes her emotional. Seventh, a trait of confidence, Allison and Noah are confident in their own way. They believed in their ability and trusted their instinct. 
Eighth, a trait of patience, Allison and Noah patiently wait until they get what they want. They do not complain when facing difficulties. Ninth, a trait of carefree, Allison, and Nao were happy when they spent time together. When They were delighted, they did not feel worried and insecure. Tenth, a trait of responsible, they faced their own problems and willing to take responsibility dor the things that caused problems. Eleventh, a trait of independence, they did not depend on others in solving their problems. Allison did not care about what others think she must do, especially when it is about her carrier, relationship, and the path she is chosen. It same goes to Noah. He lived his life based on what he wanted. Based on the traits above, it strongly proofs Noah Calhoun and Allison Nelson strongly represent liberal feminism traits.

The Notebook novel is a bestseller novel. The romantic novel was written by a successful author named Nicholas Sparks. The novel has an inspiring story about a couple who fight for love. Many aspects of the book can be analyzed, for instance, feminism, a class issue, basic human values, the main character's struggles, and others. This research only focused on the traits of the main characters as a liberal feminist. Therefore, other aspects could not be discussed in the novel. The present study could inspire those who interested in analyzing popular novels to conduct the same research. The future researcher could conduct the same research by using different theory and method.

\section{REFERENCES}

Brannon, L. (2015). Gender Psychology Perspectives (Sixth Edition ed.). New York: Routledge.

Bülbül, A. E., \& Arslan, C. (2017). Investigation of Patience Tendency Levels in Terms of Self-determination, Self-compassion and Personality Features. Universal Journal of Educational Research, 5(9), 1632-1645. https://doi.org/10.13189/ujer.2017.050921

Crowther, J. (1995). Oxford Advanced Learner's Dictionary. Oxford: Oxford University Press.

Dinata, A. (2011). Menjadi Pribadi Tangguh. Inside, 5(1), 54-55.

Disch, H. (2018). The oxford Handbook of Feminist Theory. United States of Amerika: Oxford University Press.

Eidelweis, R. V. P. (2018). Liberal Feminism as Reflected in The Main Character of Joy Movie. Diponegoro University.

Fajarini, Y. A. (2015). Devotion in Nicholas Sparks' the Notebook ( 1996 ): an Individual Psychological Approach. Muhammadiyah University of Surakarta, (1996), 1-2.

Fakhrian, A., \& Islamiyati, D. N. (2017). Reading the Values of Liberal Feminism in Hillary Clinton'S Speech At the Democratic National Convention 2016. OKARA:

Jurnal Bahasa Dan Sastra, 11(2), 277-286. https://doi.org/10.19105/ojbs.v11i2.1494

Ferracioli, L. (2020). Carefreeness and Children's Wellbeing. Journal of Applied Philosophy, 37(1), 103-117. https://doi.org/10.1111/japp.12382

Firmness. (2020). In Merriam-Webster's collegiate dictionary. Retrieved June 28, 2020, from https://www.merriam-webster.com/dictionary/firmness 
Forceful. (2020). In Cambridge Dictionary. Retrieved May 31, 2020, from https://dictionary.cambridge.org/dictionary/english/forceful

Frey, L., Bontan, C., \& Kreps, G. (1999). An Introduction to Research Method (second edition). Boston: Allyn \& Bacon.

Grimen, H. L., \& Diseth, Å. (2016). Sensory Processing Sensitivity: Factors of the Highly Sensitive Person Scale and Their relationships to Personality and Subjective Health Complaints. Comprehensive Psychology, 5, 1-10. https://doi.org/10.1177/2165222816660077

Hendriana, E. C., \& Jacobus, A. (2016). Implementasi Pendidikan Karakter di Sekolah Melalui Keteladanan dan Pembiasaan. Jurnal Pendidikan Dasar Indonesia, 1(2), 25-29.

Jayanti, R. A. D. (2013). An Analysis of Feminism Portrayed in the Main Character, Elizabeth Bennet, in Jane Austen's Pride and Prejudice. Islamic Collage Tulungagung.

Joy, A. (2019). Review The Notebook Nicholas Spark. IJCIRAS, 1(11), 74-75.

Lubis, S. (2006). Gerakan Feminisme dalam Era Postmodernisme Abad 21. Jurnal Ilmu Politik Kenegaraan, 2(1), 73-81.

Marilley, S. M. (1996). Woman Suffrage and the Origins of Liberal Feminism in the United States, 1820-1920. Woman Suffrage and the Origins of Liberal Feminism in the United States, 1820-1920. United States of America: Library of Congress Cataloging-in-Publication Data. https://doi.org/10.4159/harvard.9780674431331

McKee, A. (2003). A beginner's guide to textual analysis. Metro Magazine. London: Sage Publication Ltd.

Miles, M. B., \& A. Huberman, M. (1994). Qualitative Data Analysis (Seconded). United States of America: Sage Publication Ltd.

Murthi, Y. H., Kartikasari, D., Misiyah, Susilo, Z. K., Nikmah, S. K., \& Santono, H. (2017). Mewujudkan Kesetaraan Gender. International NGO Forum on Indonesian Develompment, (September), 1-72.

Patience. (2020). In Cambridge Dictionary. Retrieved June 13, 2020, from https://dictionary.cambridge.org/dictionary/english/patience

Payani, N. L. P. D., Suwastini, N. K. A., \& Swandana, I. W. (2018). The Identification of Character of Education Values on the Main Character of Zootopia. Ganesha University.

Rastina, Sili, S., \& Nasrullah. (2019). Masculinity Traits of Maud Watts as a Female Character in the Suffragette Film. Jurnal Ilmu Budaya, 3(3), 268-276.

Responsible. (2020). In Cambridge Dictionary. Retrieved June 13, 2020, from https://dictionary.cambridge.org/dictionary/english/responsible

Roifah, M. (2014). Reading The Notebook by Nicholas Sparks: The Effects of Popular Romance Novel Readership on Women Romance Novel. DIGLOSSIA, 5(2), 68-77.

Sensitive. (2020). In Merriam-Webster's collegiate dictionary. Retrieved June 13, 2020, from https://www.merriam-webster.com/dictionary/sensitive 
Sparks, N. (1996). The Notebook. New York: Warner Books.

Swirsky, J., \& Angelone, D. (2014). Equality, empowerment, and choice: what does feminism mean to contemporary women? Journal of Gender Studies. https://doi.org/DOI:10.1080/09589236.2015.1008429.

Tong, R. (2009). Feminism Thought: A More Comprehensive Introduction. United States of America: Westview Press.

Walters, M. (2005). Feminism: A Very Short Introduction. United States of America: Oxford University Press. Retrieved from http://www.amazon.com/dp/0192853783 